\title{
Effect of fragmentation and pacing at spot ploughing on dry soils
}

\author{
Bakhadir Mirzaev 1,* , Farmon Mamatov ${ }^{2}$, Ismoil Ergashev ${ }^{3}$, Hamraqul Ravshanov ${ }^{2}$, \\ Sherzodxuja Mirzaxodjaev ${ }^{2}$, Sherzod Kurbanov ${ }^{2}$, Uchqun Kodirov ${ }^{2}$, and Gayrat Ergashev ${ }^{2}$ \\ ${ }^{1}$ Tashkent Institute of Irrigation and Agricultural Mechanization Engineers, Tashkent 100000, \\ Uzbekistan \\ ${ }^{2}$ Karshi branch of Tashkent Institute of Irrigation and Agricultural Mechanization Engineers, Karshi \\ 180100, Uzbekistan \\ ${ }^{3}$ Samarkand Veterinary-Medicine Institute, Samarkand 140103, Uzbekistan
}

\begin{abstract}
Seedbed preparation to achieve desired aggregate size requires many tillage operations when performed on dry soil. A very common implement used for the initial operation is the moldboard plough, subsequent passes may include disk, chisel ploughs, cultivators, rototillers and harrows. Therefore ploughing should form flat soil surface to ensure favorable conditions for performance of subsequent operations. Mechanical reconsolidation by fragmenting and packing at spot ploughing on dry soils was studied in a soil bin, and on loam soil in the field. The results show that in dry soil fragmentation by ploughing and packing is attained by tearing the natural clods from each other and by stressing and translocating them. The maximum bulk density after ploughing was about $964 \mathrm{~kg} \mathrm{~m}^{-3}$, after ploughing and packing was about $1071 \mathrm{~kg} \mathrm{~m}^{-3}$. Packing considerably reduced soil surface roughness from about $0.12 \mathrm{~m}$ to $0.04 \mathrm{~m}$. Moreover, packing by rolling increased soil fragmentation from about 68.2 $\%$ (after ploughing) to $79.8 \%$. A series of experiments showed that the roller had only a slight influence on draught resistance. The spot ploughing draught were increased about $1.3 \%$ at this operating conditions.
\end{abstract}

\section{Introduction}

For second crops, as a rule, dry soils are ploughed just before drilling of summer-sown crops such as maize. Consequently, there is no time available for desirable reconsolidation of the ploughed soil by natural forces. A very common implement used in arid semiarid regions for the initial operation is the moldboard plough. In an dry; clod-forming soil, the soil bulk is made of large hard clods. Therefore seedbed preparation to achieve a desired aggregate size and reconsolidation requires many tillage operations when performed on dry soils. These operations may include disk, cultivators, chisel ploughs, harrows and other [1]. In summer time it takes more time, leads to evaporation of soil water and decresing soil moisture content, negatively influences plant density and yield [2].

\footnotetext{
Corresponding author: mirzayev.bakhadir@bk.ru
} 
The quality of soil preparation mainly depends on ploughing. The plough buries residues and weeds to create desired seedbed, it also improves soil aeration for providing enough oxygen to decompose plant residues left in the field.

However, conventional mouldboard ploughing has some shortcomings. The first is soil displacement caused by ploughing. In [3] are proposed theoretical analysis that at conventional mouldboard ploughing 1 ha on the depth $0.30 \mathrm{~m}$ only on displacement of soil spent up to $5.106 \mathrm{~J}$. energy.

Secondly, conventional mouldboard ploughing does not form flat and smooth soil surface caused by soil displacement. It does not ensure favorable conditions for performance of following operations.

The third is the structural difficulty of combining with additional implements.

In addition to shortcomings of mouldboard ploughing may include vulnerability of the ploughed soil to erosion, forming compacted soil layer, more labor and energy input.

It is designed new concept plough to invert soil slice at the same position [4-12]. According to the new concept soil slice invert within its own furrow without lateral displacement.

There are several names for the ploughs satisfying new technology of ploughing: 'Frontal plough' [4, 7, 10, 12], 'Spot plough' [11, 13, 14], Inverting plough [15], 'Parallel plough' [16].

Benefits ot the spot plough are symmetric alignment of the units $[4,7,10,12]$, potential for combining with other working implements [17], forming flat soil surface, reduce the draught $[7,10,12,18-26]$.

The work reported here attempts to estimate efficiency of spot ploughing on dry soils with supplementary working unit (roller) for fragmenting and packing of soil.

\section{Materials and methods}

The model of roller was tested in the soil bin. The roller was mounted on a moving trolley. The trolley was operated at speeds of $1.0-1.5 \mathrm{mc}^{-1}$. Soils were prepared by pressing by packers. Soil moisture content was about $16.4-20.0 \%$, bulk density $800-900 \mathrm{~kg} \mathrm{~m}^{-3}$, cone penetration resistance $0.3-0.4 \mathrm{MPa}$.

View of a roller is shown in Figure 1.

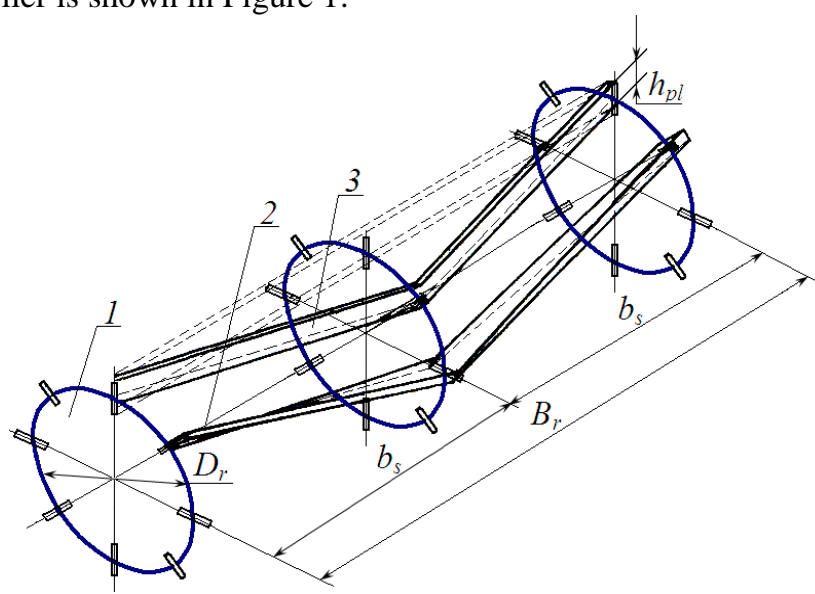

Fig. 1. Schematic view of the roller and its parameters (1) disk; (2) axis; (3) planks; $D$-diameter; $h_{p l^{-}}$ height of plank; $\gamma_{p l}$-installation angle of plank; $b_{s^{-}}$width of section; $\mathrm{B}_{r^{-}}$width of roller. 
The model spot plough with mounted roller was tested on loam soil in the field located at Samarkand region of Uzbekistan. The crops commonly grown are wheat and cotton for the last 40 years. Figure 2 shows model spot plough designed for field testing. It consists of two symmetrical main mouldboards ( 1 and 2 ), sub-mouldboards ( 3 and 4 ), roller 5, pressing springs 6; wheels 7 .
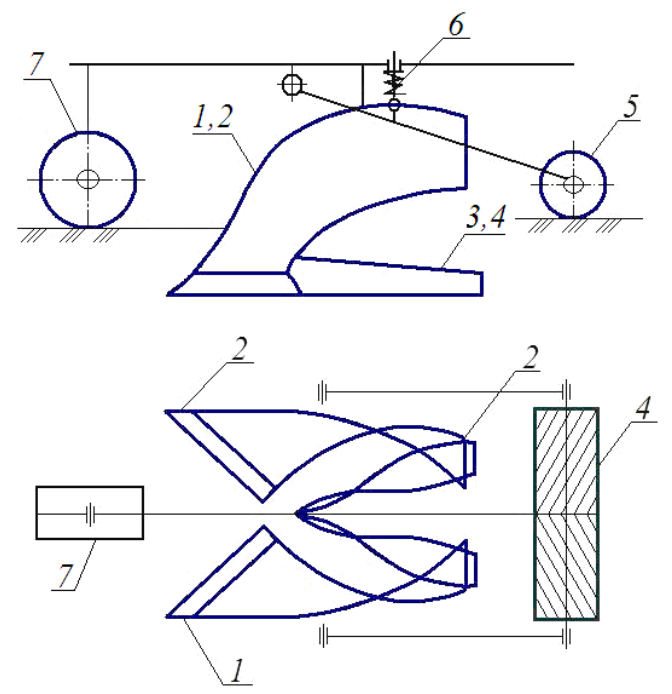

Fig. 2. Schematic view of model spot plough combined with roller: 1, 2- main moldboards; 3, 4sub moldboards; 5 - roller; 6 - pressing springs; 7 - wheel.

The vertical load on roller can be changed by compression of a springs. Soil type is typical grey soils (serozem), moisture content on horizons $0-0.10,0.10-0.20,0.20-0.25 \mathrm{~m}$ respectively was $12.7 \pm 0,5 ; 13.5 \pm 0.5 ; 14.2 \pm 0.5 \%$, cone penetration resistance respectively $2.67 \pm 0.2 \mathrm{MPa} ; 2.97 \pm 0.3 \mathrm{MPa}$ and $3.12 \pm 0.3 \mathrm{MPa}$.

Spot plough plus roller combination experiments were carried out at the depth of tillage about $0.25 \mathrm{~m}$, with a forward speed of about $1.65 \mathrm{~ms}^{-1}$.

Soil parameters measured in the field and soil bin were:

a) moisture content in the tilled layer;

b) aggregate size distribution;

c) bulk density;

d) soil surface roughness;

e) cone penetration résistance.

Aggregate size distribution was studied in 5 replications on each passes by collecting the tilled soil from blocks of $0.25 \times 0.5 \times 0.5 \mathrm{~m}$ and by sieving it through a set of sieves of different mesh sizes. Aggregates less then $50 \mathrm{~mm}$ were regarded as the characteristics of fragmenting degree.

Soil bulk density was measured by means of $100 \mathrm{sm} 3$ core samples from the $0-0.05 \mathrm{~m}$, $0.05-0.10,0.10-0.15,0.15-0.20$ and $0.20-0.25 \mathrm{~m}$ depths.

Soil surface roughness was measured before and after ploughing and after rolling by plank reliefmeter of $1-\mathrm{m}$ length fitted with vertical measuring rods with $0.05 \mathrm{~m}$ spacing. Average magnitude of 20 measurements in 5 replication regarded as characteristics of soil surface roughness.

Cone resistance was measured by penetrometer Goryachkin (cone angle 300, base area $3.2 \mathrm{~cm} 2$ ) before ploughing, after ploughing and after rolling.

Draught forces were measured by integrating tenzometric Triangle designed by VISHOM [27]. 


\section{Results and discussions}

Laboratory experiments of roller were carried out in soil bin. Results of these experiments are presented in Figure 3.

Functioning of the roller generally depends on it's diameter $(D)$ (see Fig 3, a and b), number of plank $\left(n_{p l}\right)$ (see Fig 4$)$ and an installing angle $\left(\gamma_{p l}\right)$ of planks (see Fig 5).

Penetration resistance $\mathrm{T}$ and bulk density $\rho$ decreased with an increase in diameter of the roller The distance between planks increases with increase the diameter that reduced the penetration resistance, bulk density (see Fig 3, a), fragmentation of soil $F$, soil surface roughness increased (see Fig 3, b).

Variability of penetrate resistance $\Delta T$ was negatively related with the number of roller planks (see Fig. 4). The degree of fragmentation increased with an increase of number of prank, soil surface roughness decreased. At number of plank more than 10 changing rates of fragmenting and soil surface roughness reduced.

The influence of installing angle of the plank on fragmenting of soil not so big (about $4 \ldots .5 \%$ ), but on soil surface roughness is significant (see Fig. 5). Under small installing angles of the plank fragmentation improves due to compression of clods by plank, but under greater angles the displacement of soil clods by plank occurs. Herewith fragmentation is attained by tearing the natural clods from each other and by stressing and translocating them. In dry clod forming soils fragmenting of soil on ploughing generally occurs under the same circumstances.

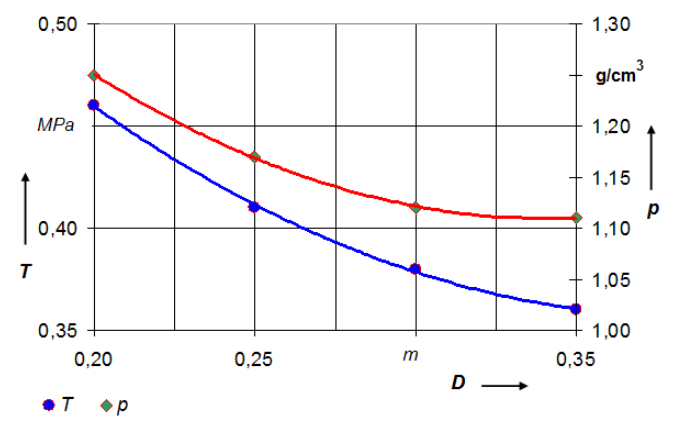

a)

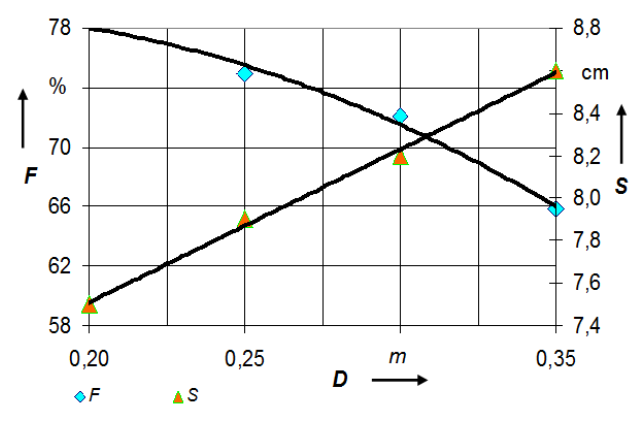

b)

Fig. 3. Influence of diameter $D$ of roller on: (a) penetrate resistance $T$ and bulk density $\rho$; (b) fragmenting degree $F$ and soil surface roughness $S$. 


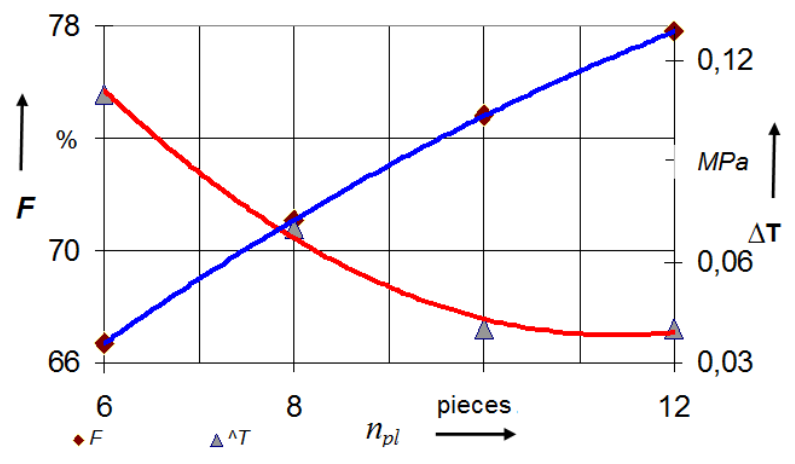

Fig. 4. Influence of number of planks $n_{p l}$ on fragmenting degree $F$ and variability of penetration resistance $\Delta T$.

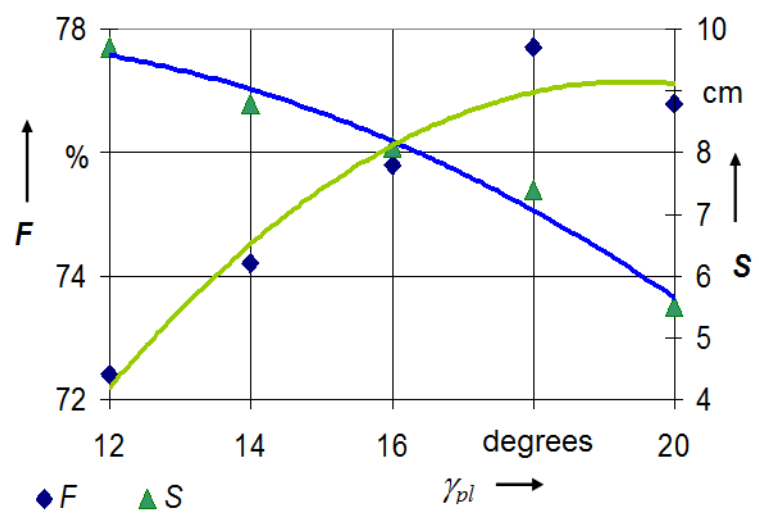

Fig. 5. Influence of installation angle of plank $\gamma_{p l}$ on fragmenting degree $F$ and soil surface roughness $S$.

As a result of laboratory studies for field test combined with spot plough roller was manufactured under following parameters; $D=0,3 \mathrm{~m}, n_{p l}=10 ; \gamma_{p l}=19^{0}$

Field experiments of Spot plough plus roller allow to establish terms for their joint operation, degree of influence of roller on functioning of plough.

Figure 6 presents some typical penetrometer results (a) measurements of bulk density (b) obtained immediately after spot plouging and rolling. 

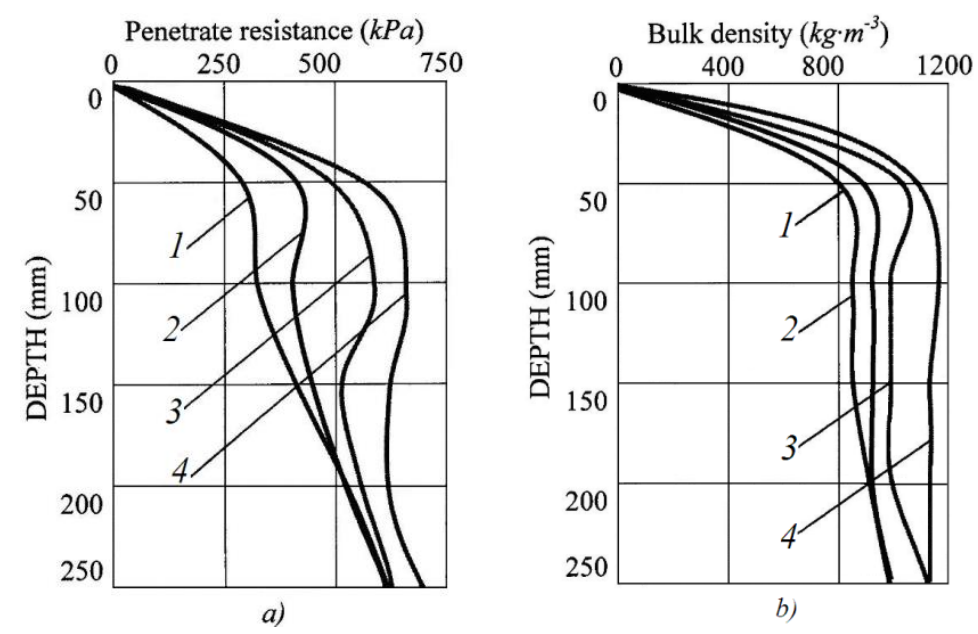

Fig. 6. Influence of vertical load on roller to penetrate resistance (a) and bulk density (b) just after spot ploughing and rolling: 1-control (spot ploughing only); 2,3,4-after spot ploughing plus rolling (vertical load on the roller respectively $500 \mathrm{~N}(2), 1000 \mathrm{~N}(3), 1500 \mathrm{~N}(4))$.

The rolling increased soil penetrates resistance and bulk density. The depth of influencing and its magnitude depend on vertical load on the roller (weight of roller plus compression force of the springs). The maximum increasing of penetrate resistance occurs at $0.05-0.10 \mathrm{~m}$ depth (see Fig.6,a). The maximum bulk density after ploughing was $964 \mathrm{~kg}$ $\mathrm{m}^{-3}$ at the depth $0.25 \mathrm{~m}$, caused by influencing of upper soil layer and by inverting dry compacted soil on the bottom of furrow. After rolling the maximum soil bulk density was $1071 \mathrm{~kg} \mathrm{~m}^{-3}$ at $0.10 \mathrm{~m}$ depth (see Fig.6,a).

The fragmenting of soil increased with an increase in vertical load on the roller, soil surface roughness decreased significantly. However magnitude of vertical load on roller is limited of ensuring of stability of the spot plough on depth of the tillage. Main results of the studies are reflected in the Table 1.

Figure 7 shows cross-section of tilled layer. After spot ploughing, wave form of soil surface would occur. In the inverting soil slice is deformed, increases in volume, that leads to incomplete inversion of the soil. As a result soil ridge by height $0.08-0.14 \mathrm{~m}$ is formed on the middle of main moldboards, which depends on forward speed, soil properties, depth of tillage. It is obviously seen for two passes of the plough (see Fig.7).

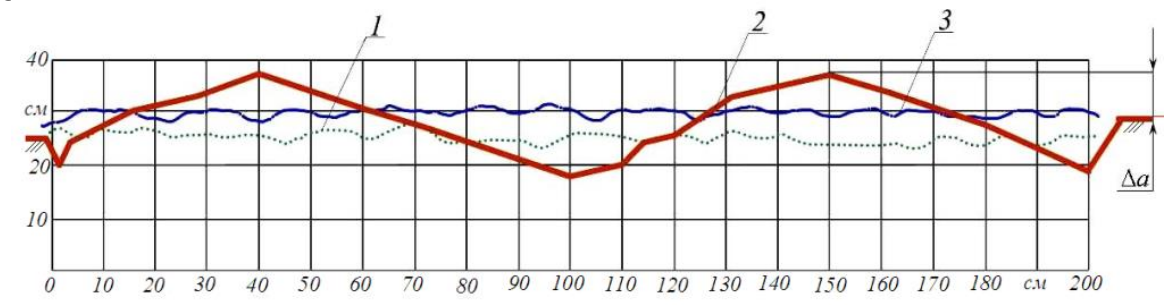

Fig. 7. Cross-section through the surface layer before (1) and after spot ploughing (2), after spot ploughing and rolling (3). 
Table 1. Average values of compared tillage treatments.

\begin{tabular}{|c|c|c|c|c|c|}
\hline Implements & $\begin{array}{c}\text { Maximum } \\
\text { bulk } \\
\text { density, } \\
\mathrm{kg} \cdot \mathrm{m}^{-3}\end{array}$ & $\begin{array}{c}\text { Maximum } \\
\text { cone } \\
\text { penetration. } \\
\text { resistance, } \\
\mathrm{kPa}\end{array}$ & $\begin{array}{c}\text { Soil surface } \\
\text { roughness, } \\
\mathrm{m}\end{array}$ & $\begin{array}{c}\text { Fragmenting, } \\
\text { (\% aggregates } \\
\text { less 50 mm) }\end{array}$ & $\begin{array}{c}\text { Average } \\
\text { draught } \\
\text { force* } \\
\mathrm{kH}\end{array}$ \\
\hline Spot plough & 964 & 630 & 0.12 & 68.2 & $12.96 \mathrm{a}$ \\
\hline $\begin{array}{c}\text { Spot plough } \\
\text { plus roller }\end{array}$ & 1071 & 750 & 0.04 & 79.8 & $13.14 \mathrm{a}$ \\
\hline
\end{tabular}

*- at the working depth $0,25 \mathrm{~m}$, width of two moldboards 1,05 m, forward speed 1,64 $\mathrm{mc}^{-1}$ a- means with (a) are not significantly different.

The results of the studies show that after rolling fragmenting of soil increased about to $11,6 \%$, soil surface roughness reduced about triple, but average draught force increased only to $1,3 \%$. Therefore spot ploughing combined with rolling ensure favorable conditions for performance of subsequent operations.

\section{Conclusions}

Rolling combined with spot ploughing improves the quality of prepared soil, creates favorable conditions for performance of subsequent operations.

1. Soil surface roughness decreased by rolling significantly.

2. Soil fragmentation by rolling increased with an increase vertical load on the roller.

3. After rolling the maximum penetrate resistance and soil bulk density was found at $0.05-0.10 \mathrm{~m}$ depth.

This project was supported by State Centre of science and technology.

\section{References}

1. A. Hadas, D. Wolf, Energy efficiency in tilling dry clod-forming soils. Soil Tillage Res., 3, 47-59 (1983)

2. M. Muradov, R. Baymetov, Texnologiya uluchsheniya plodorodiya pochv. P. 79, Tashkent (1985)

3. V.A. Sakun, On ways to reduce the energy intensity of tillage. Vestnik selskoxozyaystvennoy nauki, 3, 118-130 (1978)

4. V.A. Sakun, Ya.P. Lobachevskiy, V.V. Sharov, Frontal plows. Zemledeliye, 9, 53-54 (1983)

5. B.M. Shmelev, Auger plough for flat ploughing. Tractory i Seikhozmashiny, 3, 24-26 (1985)

6. N. Kawamura, K. Takakita, T. Niyamapa, New concept plow to invert furrow slice at the same position. In. Res. Report on Agricultural Mach., 16, 3-16, Kyoto University, Kyoto, Japan, (1986)

7. V.V. Sharov, Justification of the main parameters of a rotary plow for smooth plowing. Diss. kand. texn. nauk., Moscow, p. 189 (1986)

8. K. Shoji, K. Namikawa, M. Umeda, Evaluation and modification on the new concept plow. In; Proc. Of the Intern. Conf. for Agric. Mach. and Process Eng., 4, Korean Society for Agricultural Machinery, Seoul, Korea, 1026-1035 (1993) 
9. J. Kamide, S. Wang, Study on a plow to invert furrow slice at the same position (Patr 1) - the concept of a new plow and some experiments on inverting furrow slice. J. of the Jap. Agr. Mach., 55 (3), 15-22 (1993)

10. Y.P. Lobachevsky, New technology of the flat ploughing and design of the front ploughs. ASAE Paper No/ 961071 (1996)

11. K. Shoji, Design of a Model 'Spot Plough' for inversion of the Soil Slice within the Furrow. J. Agric.Eng. Res., 79 (3), 283-297 (2001)

12. F.M. Mamatov, I.T. Ergashev, Mechanics and technological foundations of smooth beardless plowing. Tashkent, Fan, p. 172 (2003)

13. K. Shoji, Design of spot plow with single moldboard perrow. Scie. Rep. of Facult. of Agric, Kobe University, 22 (1), 57-61 (1996)

14. K. Shoji, Design and evaluation of a 'Spot Plow' with helicoidal moldboard surface and free-rotational wheel. ASAE Paper 971097 (1997)

15. L.C. Kaufman, D.S. Totten, Development of an inverting moldboard plow. Transactions of the ASAE, 15 (1), 55-60 (1972)

16. Farm Line. Parallel ploughs. A New Product Catalogue (Farm Line AB), Gasverksvagen, 4, 611 35, Nykoping, Sweden

17. J.S. McKibben, A tool for strip tilling and planting row crops. Transactions of the ASAE, 9 (2), 151-154 (1966)

18. F.M. Mamatov, I.T. Ergashev, New Smooth Plowing Technology. Vestnik agrarnoy nauki Uzbekistana, 1, 75-76, Tashkent (2001)

19. F.M. Mamatov, B.S. Mirzaev, Justification of a rational method for layers turnover with a ridge-stepped ploughing. Scie. and Tech., 4, 27-34 (2014)

20. B.S., Mirzaev, F.M. Mamatov, I.J. Avazov, Sh.H. Mardonov, Technologies and technical means for anti-erosion differentiated soil treatment system. E3S Web of Conf., 97(05036) (2019)

21. B.S. Mirzaev, F.M. Mamatov, O.B. Tursunov, A justification of broach-plow's parameters of the ridge-stepped ploughing. E3S Web of Conf., 97(05035) (2019)

22. F.M. Mamatov, B.S. Mirzaev, Plow for ridge-step ploughing with subsoilers like "paraplau" type. Rep. of the Acad. of Scie. of the Repub. of Uzbekistan, 4, 33-36 (2014)

23. F.M. Mamatov, B.S. Mirzaev, Soil protection and moisture saving technologies and tools for tillage. Eur. Appl. Scie., 9, 115-117 (2013)

24. F.M. Mamatov, B.S. Mirzaev, Erosion preventive technology of crested ladder-shaped tillage and plow design. Eur. Appl. Scie., 4, 71-73 (2014)

25. F.M. Mamatov, B.S. Mirzaev, Theoretical definition of chisel's working body traction resistance of the ,,paraplau“ type. Probl. in Mech., 3, 172-176 (2014)

26. F.M. Mamatov, B.S. Mirzaev, The quality of soil loosening theoretical determination by a two-stage ripper with working bordies of an inclined type. TashSTU, 3, 108-112 (2014)

27. G.G.Kleyman, Strain gauge triangle for agricultural machinery. Traktori i Selxozmashini, 12, 23-25 (1979) 